\title{
Effects of different culture conditions on biological potential and metabolites production in three Penicillium isolates
}

Filipa S. Reis, ${ }^{a}$ Ana Ćirić, ${ }^{b}$ Dejan Stojković, ${ }^{b}$ Lillian Barros, ${ }^{a}$ Milica LjaljevićGrbić, ${ }^{c}$ Marina Soković, ${ }^{\mathrm{b}, *}$ IsABel C.F.R. Ferreira ${ }^{\mathrm{a}, *}$

${ }^{\mathrm{a}}$ Mountain Research Center (CIMO), ESA, Polytechnic Institute of Bragança, Campus de Santa Apolónia, Ap. 1172, 5301-855 Bragança, Portugal.

${ }^{\mathrm{b}}$ University of Belgrade, Department of Plant Physiology, Institute for Biological Research "Siniša Stanković", Bulevar Despota Stefana 142, 11000 Belgrade, Serbia.

"University of Belgrade, Institute of Botany and Botanical Garden "Jevremovac", Takovska 43, 11000 Belgrade, Serbia.

* Authors to whom correspondence should be addressed (Isabel C.F.R. Ferreira; e-mail: iferreira@ipb.pt; telephone +351-273-303219; fax +351-273-325405 and Marina D. Soković; e-mail: mris@ibiss.bg.ac.rs; telephone +381-11-2078419; fax +381-112761433).

Running head: Biological potential of Penicillium isolates 


\section{ABSTRACT}

The genus Penicillium is well known for its importance in drug and food production. Certain species are produced on an industrial scale for the production of antibiotics (e.g. penicillin) or for insertion in food (e.g. cheese). In the present work, three Penicillium species, part of the natural mycobiota growing on various food products were selectedP. ochrochloron, P. funiculosum and $P$. verrucosum var. cyclopium. The objective of our study was to value these species from the point of view of production of bioactive metabolites. The species were obtained after inoculation and growth in Czapek and Malt media. Both mycelia and culture media were analyzed to monitor the production of different metabolites by each fungus and their release to the culture medium. The concentrations of sugars, organic acids, phenolic acids and tocopherols, were determined. Antioxidant activity of the phenolic extracts was evaluated, as also the antimicrobial activity of phenolic acids, organic acids and tocopherols extracts. Rhamnose, xylose, fructose and trehalose were found in all the mycelia and culture media; the prevailing organic acids were oxalic and fumaric acids, and protocatechuic and $p$-hydroxybenzoic acids were the most common phenolic acids; $\gamma$-tocopherol was the most abundant vitamin $\mathrm{E}$ isoform. Generally, the phenolic extracts corresponding to the mycelia samples revealed higher antioxidant activity. Concerning the antimicrobial activity there were some fluctuations, however all the studied species revealed activity against the tested strains. Therefore, the in vitro bioprocesses can be an alternative for the production of bioactive metabolites that can be used by pharmaceutical industry.

Keywords: Penicillium, fungi growth, metabolites, antioxidant, antimicrobial activity. 


\section{Introduction}

Molds species, especially from the genus Penicillium and similar genera (e.g. Aspergillus) are recognized nowadays as producers of several bioactive compounds and different chemicals currently used as pharmaceuticals. ${ }^{1}$ The golden age of antibiotic discovery and their isolation from Penicillium spp. dating back to the $20^{\text {th }}$ century and, these potent drugs, indisputably saved millions of lives. Thousands of Penicillium isolates have probably been screened in bioprospecting programs since the discovery of penicillin, and new bioactive metabolites continue to be discovered from these fungi at the moment, ${ }^{2,3}$ indicating their current importance as a source of novel bioactive molecules to be used by the pharmaceutical industry. Despite this fact, there are few studies containing a detailed chemical analysis of food contaminants, and their biotechnological potential. Since only a small number of species of the fungi kingdom is known, and most fungi produce unknown metabolites, molds constitute one of the most promising sources of new compounds with potential application in biotechnology, pharmaceutical and food industry. ${ }^{4}$

The Penicillium genus comprises more than 200 described species and many are common soil inhabitants, as well as food borne contaminants or food ingredients used in the preparation of cheese and sausages. ${ }^{5,6}$ Several species of Penicillium are common contaminants on various substrates and are known as potential mycotoxin producers. Human pathogenic species are rare; however, some species, like Penicillium marneffei, are known for causing severe infections. This specific species usually affects apparently immunocompetent individuals that suffered for example from tuberculosis or HIV, affecting different organs/tissues like the bone marrow, intestine, kidneys or lungs. ${ }^{7}$ Opportunistic infections leading to mycotic keratitis, otomycosis and endocarditis, often following insertion of valve prosthesis, have been also reported. ${ }^{8}$ Penicillium species 
also produce pigments ${ }^{9}$ that might be used as colorants for food industry. The studied species are food born contaminants and they are frequently used to test the molds resistance. ${ }^{10}$ However they have been studied in other fields. Penicillium ochrochloron is already known as a source of certain compounds such as penitrem A, B, C, D, E and F, bromopenitrem $\mathrm{A}$ and $\mathrm{F}$ and dehydro-penitrem $\mathrm{D} .{ }^{4}$ Filamentous fungi are often studied in the area of enzymes production. P. ochrochloron revealed bioremediation potential, since it was capable to decolorize cotton blue. ${ }^{11}$ This species is also used for the production of (1-3) $\beta$-D-glucanases and $\beta$-glucosidase. ${ }^{12}$ In addition, hemicellulases from Penicillium funiculosum, namely xylanases, have been already characterized ${ }^{13}$ and cellulases from this species revealed a hydrolytic action on paper materials. ${ }^{14}$ Penicillium verrucosum is a fungus well known as an ochratoxin producer; ${ }^{15}$ nevertheless, it has been also studied for lipase production. ${ }^{16}$

The antimicrobial activity of $P$. ochrochloron has been also proved through the isolation of two secondary metabolites with this potential, namely (-) 2,3,4-trihydroxybutanamide and (-) erythritol. ${ }^{17}$ Thus, this species could be used as a microorganism with antimicrobial properties.

Some antioxidants have also been described in Penicillium species such as $P$. citrinum $^{18}$ and P. expansum. ${ }^{19}$

The potential already demonstrated by these species as a source of different compounds, has stimulated us to study the production of other metabolites and their biological properties. The main objective of our study was to value these three Penicillium species from the point of view of the production of interesting metabolites (e.g. tocopherols or phenolic compounds) and testing their bioactivity (antioxidant and antimicrobial activities), for further application in pharmaceutical industry. For that, the studied species were grown in two different culture media - Czapek and Malt media, to further 
compare the produced metabolites and verify if the media exert some influence on the metabolites production and their release/or not (to predict possible extraction methods in future work). Then, the biological potential was assessed through four different assays to test the antioxidant activity and through the evaluation of the antimicrobial activity against a Gram-positive bacterium and one yeast species. Thus, we could infer that the produced compounds conferred bioactive properties to the fungi.

\section{Material and methods}

\section{Molds strains}

The molds used in this study were: Penicillium ochrochloron Biourge (ATCC 9112), Penicillium funiculosum Thom (ATCC 11797) and Penicillium verrucosum var. cyclopium Westling (Pvc-DS-11) isolated from spoiled cheese by Reis et al. ${ }^{20}$ The species were stored in Micromycetes Collection Unit of the Mycological Laboratory, Department of Plant Physiology, Institute for Biological Research, Belgrade.

\section{Growth and culture conditions}

The molds were maintained on malt agar (MA) medium at $25{ }^{\circ} \mathrm{C}$ for 7 days. The stock culture (7 days old) was inoculate in $150 \mathrm{~mL}$ of Czapek medium $\left(\mathrm{NaNO}_{3} 3 \mathrm{~g}, \mathrm{~K}_{2} \mathrm{HPO}_{4} 1\right.$ g, $\mathrm{MgSO}_{4} .7 \mathrm{H}_{2} \mathrm{O} 0.5 \mathrm{~g}, \mathrm{KCl} 0.5 \mathrm{~g}, \mathrm{FeSO}_{4} .7 \mathrm{H}_{2} \mathrm{O} 0.01 \mathrm{~g}$, Sucrose $30 \mathrm{~g}, \mathrm{pH} 7.0 \pm 2$ ) or in $150 \mathrm{~mL}$ of Malt medium (malt extract $50 \mathrm{~g}$, Torlak, Belgrade, Serbia) in $500 \mathrm{~mL}$ Erlenmeyer flasks. Media were sterilized by filtration using sterile filter papers. The inoculated Czapek $(\mathrm{Cz})$ flasks were then incubated at $28{ }^{\circ} \mathrm{C}$ for 15 days on a rotary shaker $(150 \mathrm{rpm})$. The inoculated flasks containing malt medium were incubated at 28 ${ }^{\circ} \mathrm{C}$ for 21 days stationary. The procedures were repeated four times in order to obtain 
enough biomass to perform all the assays. Fungal mycelia were separated from the media by filtration using Whatman filter paper $\mathrm{N}^{\mathrm{o}} 4$ and washing twice with sterile distilled water. The mycelia were dried at $37^{\circ} \mathrm{C}$ and kept at $4{ }^{\circ} \mathrm{C}$ until further use. The culture media were lyophilized and kept at $4{ }^{\circ} \mathrm{C}$ until further use.

\section{Chemicals and reagents}

Acetonitrile $99.9 \%, n$-hexane $95 \%$ and ethyl acetate $99.8 \%$ were of HPLC grade from Fisher Scientific (Lisbon, Portugal). Sugar, organic acid and tocopherol standards were purchased from Sigma (St. Louis, MO, USA). Racemic tocol, $50 \mathrm{mg} / \mathrm{mL}$, was purchased from Matreya (PA, USA). 2,2-Diphenyl-1-picrylhydrazyl (DPPH) was obtained from Alfa Aesar (Ward Hill, MA, USA) and trolox (6-hydroxy-2,5,7,8tetramethylchroman-2-carboxylic acid) was purchased from Sigma (St. Louis, MO, USA). Methanol and all other chemicals and solvents were of analytical grade. Water was treated in a Milli-Q water purification system (TGI Pure Water Systems, USA). Czapek (Cz) and Malt (MA) media were obtained from the Institute of Immunology and Virology, Torlak (Belgrade, Serbia).

\section{Free sugars extraction and analysis}

The lyophilized samples ( $1 \mathrm{~g})$ were spiked with the Internal Standard, IS (raffinose, 5 $\mathrm{mg} / \mathrm{mL}$ ), and were extracted with $40 \mathrm{~mL}$ of $80 \%$ aqueous ethanol at $80{ }^{\circ} \mathrm{C}$ for $1 \mathrm{~h} 30 \mathrm{~min}$. The resulting suspension was filtered and concentrated under reduced pressure (rotary evaporator Büchi R-210) and defatted three times with $10 \mathrm{~mL}$ of ethyl ether, successively. After concentration, the residues were dissolved in water to a final volume of $5 \mathrm{~mL}$, filtered through a $0.22 \mu \mathrm{m}$ disposable LC filter disk, transferred into an injection vial and analysed by High Performance Liquid Chromatography (HPLC) 
consisting of an integrated system with a pump (Knauer, Smartline system 1000), degasser system (Smartline manager 5000) and auto-sampler (AS-2057 Jasco), coupled to a refraction index detector (RI detector Knauer Smartline 2300). The chromatographic separation was achieved with an Eurospher 100-5 $\mathrm{NH}_{2}$ column (4.6 $\mathrm{mm} \times 250 \mathrm{~mm}, 5 \mathrm{~mm}$, Knauer) operating at $35{ }^{\circ} \mathrm{C}$ (7971R Grace oven). The mobile phase used was acetonitrile/deionized water, 70:30 (v/v) at a flow rate of $1 \mathrm{~mL} / \mathrm{min}$, and

the injection volume was $20 \mu \mathrm{L}{ }^{21}$ Sugars identification was made by comparing the relative retention times of sample peaks with standards. Data were analyzed using Clarity 2.4 Software (DataApex). Quantification was based on the RI signal response of each standard, using the IS method and by using calibration curves obtained from commercial standards of each compound. The results were expressed in mg per $g$ of dry weight.

\section{Organic acids extraction and analysis}

The lyophilized samples (1.5 g) were extracted by stirring with $25 \mathrm{~mL}$ of metaphosphoric acid $\left(25^{\circ} \mathrm{C}\right.$ at $\left.150 \mathrm{rpm}\right)$ for $45 \mathrm{~min}$ and subsequently filtered through Whatman $\mathrm{N}^{\mathrm{o}} 4$ paper. Before the analysis by HPLC (Shimadzu 20A series UFLC), the sample was filtered through $0.2 \mu \mathrm{m}$ nylon filters. Separation was achieved on a Sphere Clone (Phenomenex) reverse phase $\mathrm{C}_{18}$ column $(5 \mu \mathrm{m}, 250 \mathrm{~mm} \times 4.6 \mathrm{~mm}$ i.d) thermostatted at $35^{\circ} \mathrm{C}$. The elution was performed with sulphuric acid $3.6 \mathrm{mM}$ using a flow rate of $0.8 \mathrm{~mL} / \mathrm{min}$. Detection was carried out in a photodiode array detector (PDA), using $215 \mathrm{~nm}$ and 245 as preferred wavelengths. ${ }^{22}$ The organic acids were quantified by comparison of the area of their peaks recorded at $215 \mathrm{~nm}$ with calibration curves obtained from commercial standards of each compound. The results were expressed in mg per g of dry weight. 


\section{Phenolic acids extraction and analysis}

The lyophilized samples ( $1 \mathrm{~g})$ were extracted with methanol:water $(80: 20, \mathrm{v} / \mathrm{v} ; 30 \mathrm{ml})$ at $-20^{\circ} \mathrm{C}$ for $1.5 \mathrm{~h}$. After sonication for $15 \mathrm{~min}$, the extract was filtered through Whatman No. 4 paper. The residue was then re-extracted with an additional $30 \mathrm{ml}$ portion of the methanol:water mixture. Combined extracts were evaporated under reduced pressure to remove the methanol. The aqueous phase was washed with diethyl ether $(2 \times 20 \mathrm{ml})$ and ethyl acetate $(2 \times 20 \mathrm{ml})$. To the combined aqueous phases, anhydrous sodium sulphate was added and the extracts were filtered through Whatman $n^{\circ} 4$ paper, evaporated to dryness and then re-dissolved in methanol:water $(80: 20, \mathrm{v} / \mathrm{v})$. The extracts $(1 \mathrm{ml})$ were filtered through a $0.22 \mu \mathrm{m}$ disposable LC filter disk for HPLC analysis. The analysis was performed by HPLC (equipment described above). Detection was carried out in a PDA using $280 \mathrm{~nm}$ as the preferred wavelength. ${ }^{23}$ The phenolic compounds were characterized according to their UV and mass spectra and retention times, and comparison with authentic standards when available. The identified phenolic acids were quantified by comparison of the area of their peaks recorded at $280 \mathrm{~nm}$ with calibration curves obtained from commercial standards of each compound. The results were expressed in $\mu \mathrm{g}$ per g of dry weight.

\section{Tocopherols extraction and analysis}

BHT solution $(100 \mu \mathrm{L})$ and IS solution (tocol, $250 \mu \mathrm{L}$ ) were added to the sample prior to the extraction procedure. The lyophilized samples $(\sim 500 \mathrm{mg})$ were homogenized with methanol $(4 \mathrm{~mL})$ by vortex mixing $(1 \mathrm{~min})$. Subsequently, hexane $(4 \mathrm{~mL})$ was added and again vortex mixed for $1 \mathrm{~min}$. After that, saturated $\mathrm{NaCl}$ aqueous solution $(2 \mathrm{~mL})$ was added, the mixture was homogenized (1 min), centrifuged (5 min, 4000g) and the clear upper layer was carefully transferred to a vial. The sample was re-extracted twice 
with hexane. The combined extracts were taken to dryness under a nitrogen stream, redissolved in $1 \mathrm{~mL}$ of hexane, dehydrated with anhydrous sodium sulphate, filtered through a $0.22 \mu \mathrm{m}$ disposable LC filter disk, transferred into a dark injection vial and analysed by HPLC (equipment described above for sugars analysis), and a fluorescence detector (FP-2020; Jasco) programmed for excitation at $290 \mathrm{~nm}$ and emission at 330 nm. Data were analysed using Clarity 2.4 Software (DataApex). The chromatographic separation was achieved with a Polyamide II $(250 \times 4.6 \mathrm{~mm})$ normal-phase column from YMC Waters (Japan) operating at $35{ }^{\circ} \mathrm{C}$. The mobile phase used was a mixture of hexane and ethyl acetate $(70: 30, \mathrm{v} / \mathrm{v})$ at a flow rate of $1 \mathrm{ml} / \mathrm{min}$, and the injection volume was $20 \mu \mathrm{L} .{ }^{24}$ The compounds were identified by chromatographic comparisons with authentic standards. Quantification was based on the fluorescence signal response of each standard, using the IS method and by using calibration curves obtained from commercial standards of each compound. The results were expressed in $\mu \mathrm{g}$ per $\mathrm{g}$ of dry weight.

\section{Antioxidant activity of phenolic acids extract}

From the phenolic acids extract (PHA) mentioned above, successive dilutions were made from a stock solution at a concentration of $20 \mathrm{mg} / \mathrm{mL}$ for mycelia and $50 \mathrm{mg} / \mathrm{mL}$ for culture media. These methanolic solutions were then submitted to distinct in vitro assays already described by Reis et al. ${ }^{20}$ The results were expressed in $\mathrm{EC}_{50}$ values (sample concentration providing $50 \%$ of antioxidant activity or 0.5 of absorbance in the Ferricyanide/Prussian blue assay). Trolox was used as standard.

Reducing power was evaluated by Folin-Ciocalteu and Ferricyanide/Prussian blue assays. The first one measures the reduction of Folin-Ciocalteu reagent by the samples, expressed as mg of gallic acid equivalents (GAE) per $\mathrm{g}$ of extract. The second one 
evaluates the capacity of the samples to convert $\mathrm{Fe}^{3+}$ into $\mathrm{Fe}^{2+}$, measuring the absorbance at $690 \mathrm{~nm}$ in an ELX800 microplate reader (Bio-Tek Instruments, Inc; Winooski, USA). DPPH radical-scavenging activity was evaluated by using the same microplate reader, and calculated as a percentage of DPPH discolouration using the formula: $\left[\left(\mathrm{A}_{\mathrm{DPPH}}-\mathrm{A}_{\mathrm{S}}\right) / \mathrm{A}_{\mathrm{DPPH}}\right] \times 100$, where $\mathrm{A}_{\mathrm{S}}$ is the absorbance of the solution containing the sample at $515 \mathrm{~nm}$, and $\mathrm{A}_{\mathrm{DPPH}}$ is the absorbance of the DPPH solution. Inhibition of $\beta$-carotene bleaching was evaluated though the $\beta$-carotene/linoleate assay; the neutralization of linoleate free radicals avoids $\beta$-carotene bleaching, which is measured by the formula: $\beta$-carotene absorbance after $2 \mathrm{~h}$ of assay/initial absorbance) $\times 100 .^{20}$

\section{Antimicrobial activity of organic acids, phenolic acids and tocopherols extracts, and individual compounds}

The antimicrobial activity was evaluated for organic acids extract (OA), phenolic acids extract (PHA) and tocopherols extract (TOC), mentioned above, and also for the compounds identified in those extracts. The extracts (obtained using different solvents according to the polarity of the compounds to be extracted and analyzed) and pure compounds were dissolved in $1 \mathrm{mg} / 100 \mathrm{~mL}$ of $5 \%$ DMSO (innocuous) before evaluation.

The Gram-positive bacterium Staphylococcus aureus (ATCC 6538) and the yeast Candida albicans (ATCC 10231) were used. The organisms were obtained from the Mycological Laboratory, Department of Plant Physiology, Institute for Biological Research "Siniša Stanković", Belgrade, Serbia.

5, 10 and $20 \mu \mathrm{L}$ of each sample (extract and pure compound) were applied on TLC plates (Kieselgel 60 F254, Merck, Art. 5721) and sprayed either with freshly prepared 
bacterial and fungal inoculum $\left(1.0 \times 10^{5} \mathrm{cfu} / \mathrm{mL}\right)$ in nutrient broth (Tryptic Soy Broth; Biolife Italiana S.r.l., Milano-Italia). The plates were incubated for $24 \mathrm{~h}$ at $37^{\circ} \mathrm{C}$ and then sprayed with aqueous sol. $3 \%$ of INT (p-iodonitrotetrazolium violet) [2-(4iodophenyl)-3-(4-nitrphenyl)-5-phenyltetrazolium chloride; Sigma], stored for another 3 $\mathrm{h}$ and sprayed with $70 \% \mathrm{EtOH}$ to stop bacterial and fungal growth. White inhibition zones on a pinkish background were indicative of the antimicrobial activity of the tested extracts. The widths of these zones $(\mathrm{mm})$ were the measure of efficiency. The antimicrobial activity was evaluated as the diameters of the inhibition zones with standard errors. ${ }^{25}$ All the experiments were performed in duplicate and replicated three times. Streptomycin (Galenika, Belgrade), and commercial fungicide fluconazole (F8929, Sigma-Aldrich St. Louis, MO) were used as positive controls (5-20 mg/spot).

\section{Statistical analysis}

For statistical analysis, three samples were used and all the assays were carried out in triplicate. The results are expressed as mean values and standard deviation (SD), and analyzed using one-way analysis of variance (ANOVA) followed by Tukey's HSD Test with $\alpha=0.05$. This analysis was carried out using SPSS v. 18.0 program.

\section{Results}

\section{Metabolites analysis}

As referred above, one way of value the studied species was the analysis of the metabolites produced by them, monitoring also the release/or not of these molecules for the culture media in order to prove the presence of such compounds and evaluate (in further works) possible methodologies of extraction. The assessed molecules were sugars (primary metabolites, however important for industry, from a nutritional point of 
they are energy producer and economically, sugars are probably the most efficient foodstuff), organic acids (result also from the primary metabolism, but some of them possess bioactive properties), phenolic acids (usually pointed as secondary metabolites produced when the species are under stress conditions, and reported as antioxidant and anticancer metabolites) and tocopherols (isoforms of vitamin E reported as bioactive compounds, especially as antioxidants).

The results of sugars composition of the studied mycelia and culture media are shown in Table 1. Concerning free sugars composition (of mycelia and culture media), rhamnose, xylose, fructose, and trehalose were presented by all the studied samples. Noted that $\mathrm{Cz}$ medium has $30 \mathrm{~g} / \mathrm{mL}$ of sucrose and this sugar was not detected in any of the samples corresponding to this medium. Since this is the carbon source provided to fungi, this leads us to believe that this sugar was metabolized.

Concerning organic acids, oxalic and fumaric acids were found in all the studied samples (Table 2). However, the latter was found in very low amounts $(0.02-0.36 \mathrm{mg} / \mathrm{g}$ dw). Organic acids were present in higher quantities in culture media (34.94 - 182.29 $\mathrm{mg} / \mathrm{g} \mathrm{dw}$ ), suggesting, once again, a release of the compounds from the fungus mycelium.

The phenolic acids detected in higher amounts were protocatechuic and $p$ hydroxybenzoic acids (Table 3). Generally, protocatechuic acid was found in all the mycelia, except in $P$. ochrochloron grown in malt medium. On the other hand, $p$ coumaric acid was only found in $P$. verrucosum var. cyclopium grown on malt medium $(8.52 \mu \mathrm{g} / \mathrm{g} \mathrm{dw})$. The samples from MA medium were those which revealed the highest content in total phenolic acids, since $P$. verrucosum var. cyclopium grown on this medium revealed $85.46 \mu \mathrm{g} / \mathrm{g}$ dw of $p$-hydroxybenzoic acid. 
Regarding tocopherols identification, $P$. ochrochloron and $P$. verrucosum var. cyclopium mycelia grown on Czapek medium, revealed the highest content in total tocopherols (11.53 and $40.96 \mu \mathrm{g} / \mathrm{g} \mathrm{dw}$, respectively; Table 4). P. ochrochloron was also the species with the highest content in tocopherols when inoculated in malt medium $(0.84 \mu \mathrm{g} / \mathrm{g} \mathrm{dw})$.

\section{Antioxidant activity of the phenolic acids extract}

As mentioned above, after the evaluation of the produced compounds, the biological properties of the species were evaluated. To test the antioxidant activity of the molds, and since there is no single method to evaluate the antioxidant activity, this property was monitored through four different assays. The results of the antioxidant properties of the phenolic extracts (PHA) obtained from the studied fungus mycelia and culture media are shown in Table 5. The species $P$. verrucosum var. cyclopium grown on both media revealed the highest reducing power measured by Folin-Ciocalteu assay (28.73 $55.83 \mathrm{mg} \mathrm{GAE} / \mathrm{g}$ extract) and by Ferricyanide/Prussian blue assay $(1.29-2.81 \mathrm{mg} / \mathrm{mL})$. This species also revealed, higher DPPH radical scavenging activity $(2.31-5.45$ $\mathrm{mg} / \mathrm{mL}$ ). Concerning $\beta$-carotene bleaching inhibition, the three fungi species, grown on Czapek medium, revealed statistically similar values $(0.11-2.38 \mathrm{mg} / \mathrm{mL})$. Analyzing data for the mentioned species grown on malt medium, the results do not differ much, being the samples with the highest $\beta$-carotene bleaching inhibition.

\section{Antimicrobial activity of organic acids, phenolic acids and tocopherols extracts, and individual compounds}

Other biological activity tested to prove the bioactivity of the metabolites produced by the studied fungi was the antimicrobial potential. The organic acids (OA), phenolic 
acids (PHA) and tocopherols (TOC) extracts activity of the species and respectively culture media was tested against the bacterium Staphylococcus aureus and the yeast Candida albicans, and the results were expressed as diameters of inhibition zones (Tables 6-8, Fig. 1). The activity of the respective extracts was tested in three different concentrations: $5 \mathrm{mg} / \mathrm{spot}, 10 \mathrm{mg} / \mathrm{spot}$ and $20 \mathrm{mg} / \mathrm{spot}$.

All the OA extracts derived both from fungal mycelia and culture media revealed antibacterial activity (it was possible to see and measure the inhibition zones; Table 6, Fig. 1). Concerning the anticandidal activity, mycelia and media presented similar values, but just for the highest concentration tested $(20 \mathrm{mg} / \mathrm{spot})$. In a concentration of 5 $\mathrm{mg} / \mathrm{spot}$ only one of the culture medium revealed activity and for the concentration of $10 \mathrm{mg} / \mathrm{spot}$ there were also some samples that do not revealed any inhibition zone. All the tested individual organic acids possessed antibacterial activity against $S$. aureus $(5.33-16.00 \mathrm{~mm})$. There were some variations in these results; however, it can be concluded that malic acid showed the best antibacterial properties for all the tested concentrations. On the other side, only oxalic and fumaric acids possessed antifungal activity against $C$. albicans, but lower than the commercial drug fluconazole (Table 6, Fig. 1).

The results of the antimicrobial activity of PHA extracts of the three tested fungi are presented in Table 7 and Fig. 1. The best antibacterial activity for the mycelia PHA extracts was achieved by $P$. ochrachloron mycelium, grown on Czapek media (18.00 $\mathrm{mm}$ ). Concerning mycelia extracts from MA medium, $P$. verrucosum var. cyclopium revealed the highest antibacterial activity. Only the mycelia PHA extracts of $P$. ochrochloron grown on $\mathrm{Cz}$ medium and $P$. verrucosum var. cyclopium grown on MA medium revealed activity against $C$. albicans. Generally, all the tested individual phenolic acids showed similar values of antibacterial inhibition against $S$. aureus, and 
higher than the commercial drug streptomycin (Table 7, Fig. 1). On the other side, only $p$-coumaric and cinnamic acids revealed antifungal activity against $C$. albicans at all the tested concentrations, the latter being the best inhibitor of this fungi species (even when compared with fluconazole).

Regarding the TOC extracts derived from fungal mycelia, the biggest inhibition zone was recorder for $P$. verrucosum var. cyclopium against $S$. aureus $(13.33-16.33 \mathrm{~mm}$; Table 8). However, all the tested samples revealed antibacterial activity (except $P$. funiculosum mycelium grown in MA medium at a concentration of $5 \mathrm{mg} / \mathrm{spot}$ ). The diameter of inhibition zones for the mycelia TOC extracts of the three tested species, grown on $\mathrm{Cz}$ medium, towards $C$. albicans, varied from 5.67-8.67 $\mathrm{mm}$ (Table 8). The TOC extracts from culture media did not revealed anticandidal activity, except $P$. funiculosum culture medium tested at the highest concentration $(7.67 \mathrm{~mm})$. TOC extracts from MA medium, generally demonstrate similar results. The studied tocopherol isoforms $(\alpha, \beta, \gamma$ and $\delta)$ on the selected Gram positive bacterium and $C$. albicans are also presented in Table 8 and Fig. 1 . Only the isomers $\gamma$ - and $\delta$-tocopherol showed antibacterial activity against $S$. aureus with inhibition zone of 5.00-10.00 mm. All the tocopherol isomers, revealed antifungal activity against $C$. albicans with different diameters of inhibition $(5.00-14.0 \mathrm{~mm})$, depended on concentration. The commercial drug streptomycin revealed lower antibacterial activity than the tested compounds $(5.00 \mathrm{~mm})$, while fluconazole shown one of the best results for anticandidal activity (11.67 - $15.00 \mathrm{~mm}$; Table 8 and Fig. 1).

\section{Discussion}

One of the most abundant sugars in the studied samples was trehalose. This could be an interesting result since this sugar seems to play an important role during the oxidative 
stress acting as an antioxidant. ${ }^{26}$ Thus, although it is a component of most immature sporocarps and may function as a reserve which is metabolized when the sporocarps are maturing ${ }^{27}$ it may also have been produced in response to stress under which the species stood.

Concerning organic acids, the main detected compounds were oxalic and fumaric acid. These organic acids play an important role in human body being part of the Krebs cycle. However, oxalic acid is usually associated to species pathogenicity. For example, during a process of pathogenesis by some fungi, this acid is produced in order to make the plant more susceptible. ${ }^{28}$ Therefore, oxalic acid may have been produced as a response to oxidative stress, since the fungi were under in vitro conditions and, when in the presence of $S$. aereus or $C$. albicans, it may be produced as a toxic element to inhibit their growth. Fumaric acid is an unsaturated dicarboxylic acid that also possesses biological effects such as anti-inflammatory, neuroprotective and chemopreventive activity. Besides, it could be also used in food industry as an antimicrobial agent for fruits and vegetables preservation, ${ }^{29,30}$ hence the importance of its synthesis. Different aspects of organic acids working mechanism with respect to their antibacterial activity are given in the review articles of Cherrington et al. ${ }^{31}$ and Russell. ${ }^{32}$ The organic acids are lipid soluble in the undissociated form, in which they are able to enter the microbial cell. Once in the cell, the acid releases the proton in the more alkaline environment, resulting in a decrease of intracellular $\mathrm{pH}$. This influences the microbial metabolism, inhibiting the action of important microbial enzymes and forces the bacterial cell to use energy to release protons, leading to an intracellular accumulation of acid anions. This accumulation depends on the $\mathrm{pH}$ gradient across the membrane. The acid anion seems to be very important regarding the antibacterial effect of organic acids and their salts. Accordingly, the production of organic acids by the fungi and their release to the media, 
it may be an answer to the stress conditions, once the molds were not in their habitat, and when placed in the presence of a foreign agent, they maybe will attempt to inhibit its growth through the production of these molecules.

Phenolic acids are composed of hydroxycinnamic and hydroxybenzoic acids. They have antioxidant activity as chelators and free radical scavengers with special impact over hydroxyl and peroxyl radicals, superoxide anions and peroxynitrites, ${ }^{33}$ hence the importance of their detection in biological sources. Phenols are also referred as molecules produced when the species are under stress conditions what may justify their production by the molds. These results could confirm that the studied species may be a source of important molecules that act as antioxidants. Comparing the antioxidant activity of the mycelium and the culture medium on which it has been developed, generally, the mycelium revealed higher antioxidant potential, as reported by other studies with different species and culture media. ${ }^{34-36}$ However, there was some antioxidant activity detected in culture media, which may suggest the release of some antioxidant compounds from the mycelia like phenolic compounds (Table 5).

The antimicrobial capacity of some phenolic compounds is well-known. ${ }^{37,38}$ They act by causing the leakage of cytoplasmic constituents such as protein, glutamate or potassium and phosphate from bacteria, which may be due to the disruption of cell peptidoglycan or damage of the cell membrane. Extracts may be more beneficial than isolated constituents, since a bioactive individual component can change its properties in the presence of other compounds present in the extract. ${ }^{39}$ The mechanism of action involves the alteration of the permeability of the cell membrane that could result in the uncoupling of oxidative phosphorylation, inhibition of active transport, and loss of pool metabolites due to the cytoplasmic membrane damage. ${ }^{40}$ Moreover, the presence of hydroxyl groups in the phenolic compound might influence their antimicrobial 
effectiveness by binding to the active site of enzymes, form hydrogen bonds with enzymes and alter their metabolism; the lipid solubility and the degree of steric hindrance of the phenolic compounds might determine also their antimicrobial activity. ${ }^{37}$ This could explain the production of these compounds by the studied fungi.

Vitamin $\mathrm{E}$ is composed of eight isoforms, with four tocopherols ( $\alpha$-tocopherol, $\beta$ tocopherol, $\gamma$-tocopherol and $\delta$-tocopherol) and four tocotrienols ( $\alpha$-tocotrienol, $\beta$ tocotrienol, $\gamma$-tocotrienoland $\delta$-tocotrienol). This vitamin halts lipid peroxidation and is the only major lipid-soluble chain breaking antioxidant found in plasma, red cells and tissues, allowing the protection of the integrity of lipid structures, mainly membranes. ${ }^{41}$ Since malt extract contained amino acids in certain amount, the biosynthesis of tocopherols in these conditions might be enhanced. Noted that the isoform found in highest quantities was $\gamma$-tocopherol, even it was not present in all the studied samples (namely in almost all culture media; Table 4). Other studies of our research group also revealed that this was the most abundant isoform present in different mycelia inoculated in different culture media. ${ }^{34}$ Thus, it seems that various genera of fungi, obtained by in vitro culture produce $\gamma$-tocopherol in higher amounts. Often, $\alpha$-tocopherol is referred as the most bioactive isoform of vitamin E. Nevertheless, other studies suggests that $\gamma$ tocopherol provides different antioxidant activities in food as also in some in vitro studies and showed higher activity in trapping lipophilic electrophiles and reactive nitrogen and oxygen species. ${ }^{42}$ With these results we can conclude that fungi can be seen as a good source of $\gamma$-tocopherol and perhaps this is a new source to explore. Studies on antimicrobial activity of tocopherol extracts from Penicillium species have not been reported earlier.

Concerning the general results for the antimicrobial activity, they were very similar between the samples. Nonetheless, there were some differences between mycelia and 
culture media. The latter almost not showed anticandidal activity; however they demonstrated some activity against $S$. aereus what could be an indicator (over again) of the release of the compounds with this activity for the culture media.

\section{CONCLUSIONS}

With this study we can conclude that the studied Penicillium species could be a source of numerous interesting molecules, namely sugars, organic acids, phenolic acids and tocopherols. The production of these molecules could be enhanced by changes in the culture media, once they have different chemical composition providing different nutrients and different answers. For example, samples grown on Czapek medium were richer in sugars, organic acids and tocopherols. These results could be interesting from the standpoint of the production of some bioactive compounds, and as the analyses were extended to the culture media and it seems that some molecules were release (because they revealed the presence of some compounds and shown antioxidant and antimicrobial potential), in future works different extraction methods for certain molecules of interest could be tested. It is unquestionable that the interest in all the types of fungal species, as possible sources of new bioactive compounds, is highly increasing. Moreover, the use of experimental design can accelerate the finding of optimal growth conditions for the production of metabolites, in agreement with the previously reported related experiments. ${ }^{43}$

This work demonstrates not only that even the considered pathogenic fungi from the Penicillium genus may be valued as a source of different molecules as they may have beneficial activities. Hence, these compounds naturally produced by fungi exhibit diverse biological effects and may also possess pharmacological activities. 


\section{Acknowledgements}

The authors are grateful to Fundação para a Ciência e a Tecnologia (FCT, Portugal), COMPETE/QREN/EU for financial support to this work (bilateral cooperation action Portugal/Serbia 2011), to CIMO (strategic project PEst-OE/AGR/UI0690/2011), and to Serbian Ministry of Education and Science for financial support (grant number 173032).

L. Barros also thanks FCT, POPH-QREN and FSE for her grant (SFRH/BPD/4609/2008).

\section{References}

1. Adrio JE, Demain AL. Fungal biotechnology. Int Microbiol 2003;6:191-199.

2. Ge HM, Shen Y, Zhu CH, Tan SH, Ding H, Song YC, Tan RX. Penicidones A-C, three cytotoxic alkaloidal metabolites of an endophytic Penicillium sp. Phytochem 2008;69:571-576

3. Takahashi JA, Lucas EMF. Occurrence and structural diversity of fungal metabolites with antibiotic activity. Quim Nova 2008;31:1807-1813.

4. Nielsen KF and Smedsgaard J. Fungal metabolite screening: database of 474 mycotoxins and fungal metabolites for dereplication by standardised liquid chromatography-UV-mass spectrometry methodology. J Chromatogr A 2003;1002:111-136.

5. Frisvad JC, Samson RA. Polyphasic taxonomy of Penicillium subgenus Penicillium: a guide to identification of food and air-borne terverticillate Penicillia and their mycotoxins. Stud Mycol 2004;49:1-173.

6. Pitt JI. A laboratory guide to common Penicillium species. CSIRO Division of Food Processing, North Ryde, New South Wales, Australia, 2000. 
7. LoBuglio KF, Taylor JW. Phylogeny and PCR identification of the human pathogenic fungus Penicillium marneffei. J Clin Microbiol 1995;33:85-89.

8. Nicoletti R, Lopez-Gresa MP, Manzo E, Carella A, Ciavatta ML.Production and fungi toxic activity of Sch 642305, a secondary metabolite of Penicillium canescens. Mycopathologia 2007;163:295-301.

9. Mapari SAS, Thrane U, Meyer AS (2010) Fungal polyketideazaphilone pigments as future natural food colorants. Trends Biotechnol 2012;28:300-307.

10. Stojković DS, Soković M, Glamočlija J, Džamić A, Ćirić A, Mihailo Ristićc, Dragoljub Grubišić. Chemical composition and antimicrobial activity of Vitexagnus-castus L. fruits and leaves essential oils. Food Chem 2011;4:10171022.

11. Shedbalkar U, Dhanve R, Jadhav J. Biodegradation of triphenylmethane dye cotton blue by Penicillium ochrochloron MTCC 517. J Hazard Mater 2008;157:472-479.

12. Jadhav JP, Dake MS, Patil NB. Separation and characterization of $\beta$-glucanases from Penicillium ochrochloron. Asian J Chem 2006;18:1191-1198.

13. Furniss CSM, Williamson G, Kroon PA. The substrate specificity and susceptibility to wheat inhibitor proteins of Penicillium funiculosum xylanases from a commercial enzyme preparation. J Sci Food Agric 2005;85:574-582.

14. vanWyk PH. Saccharification of paper products by cellulase from Penicillium funiculosum and Trichoderma reesei. Biomass and Bioenergy 1999;16:239-242.

15. Lund F and Frisvad JC. Penicillium verrucosum in wheat and barley indicates presence of ochratoxin A. J App Microbiol 2003; 95:1117-1123.

16. Kempka AP, Lipke NL, Pinheiro TLF, Menoncin S, Treichel H, Freire DMG, Luccio MD, Oliveira D. Response surface method to optimize the production and 
characterization of lipase from Penicillium verrucosum in solid-state fermentation. Bioprocess Biosyst Eng 2008;31:119-125.

17. Rančić A, Soković M, Karioti A, Vukojević J, Skaltsa H. Isolation and structural elucidation of two secondary metabolites from the filamentous fungus Penicillium ochrochloron with antimicrobial activity. Environ Toxicol Pharm 2006;22:80-84.

18. Arora SD, Chandra P. In vitro antioxidant potential of some soil fungi: Screening of functional compounds and their purification from Penicillium citrinum. Appl Biochem Biotechnol 2011;165:639-651.

19. Kim YH, Park MH, Lee CH. Mass spectrometry-based chemotaxonomic classification of Penicillium species ( $P$. echinulatum, $P$. expansum, $P$. solitum, and P.oxalicum) and its correlation with antioxidant activity. J Microbiol Meth 2012;90:327-335.

20. Reis FS, Stojković D, Soković M, Glamočlija J, Ćirić A, Barros L, Ferreira ICFR. Chemical characterization of Agaricus bohusii, antioxidant potential and antifungal preserving properties when incorporated in cream cheese. Food Res Inter 2012;48:620-626.

21. Reis FS, Barros L, Martins A, Ferreira ICFR. Chemical composition and nutritional value of the most widely appreciated cultivated mushrooms: An inter-species comparative study. Food Chem Toxicol 2012;50:191-197.

22. Barros L, Pereira C, Ferreira ICFR. Optimized analysis of organic acids in edible mushrooms from Portugal by ultra fast liquid chromatography and photodiode array detection. Food Anal Method 2013;6:309-316.

23. Barros L, Dueñas M, Ferreira ICFR, Baptista P, Santos-Buelga C. Phenolic acids determination by HPLC-DAD-ESI/MS in sixteen different Portuguese wild mushrooms species. Food Chem Toxicol 2009;47:1076-1079. 
24. Heleno SA, Barros L, Sousa MJ, Martins A, Ferreira ICFR. Tocopherols composition of Portuguese wild mushrooms with antioxidant capacity. Food Chem 2010;119:1443-1450.

25. Pacher T, Bacher M, Hofer O, Greger H.Stress induced carbazolephytoalexins in Glycosmis species. Phytochemistry 2001;58:129-135.

26. Oku K, Watanabe H, Kubota M, Fukuda S, Kurimoto M, Tsujisaka Y, Komori M, Inoue Y, Sakurai M. NMR and quantum chemical study on the $\mathrm{OH}^{\cdots}{ }^{\cdots} \pi$ and $\mathrm{CH}^{\cdots} \mathrm{O}$ interactions between trehalose and unsaturated fatty acids: implication for the mechanism of antioxidant function of trehalose. J Am Chem Soc 2003; $125: 12739-12748$.

27. Koide RT, Shumway DL, Stevens CM. Soluble carbohydrates of red pine (Pinus resinosa) mycorrhizas and mycorrhizal fungi. Mycol Res 2000;104, 834-840.

28. Nagarajkumar M, Jayaraj J, Muthukrishnan S, Bhaskaran R, Velazhahan R. Detoxification of oxalic acid by Pseudomonas fluorescens strain PfMDU2: Implications for the biological control of rice sheath blight caused by Rhizoctonia solani. Microbiol Res 2005;160: 291-298.

29. Altmeyer PJ, Mattlies U, Pawlak F, Hoffmann K, Frosch PJ, Ruppert P, Wassilew SW, Horn T, Kreysel HW, Lutz G, Barth J, Rietzschel I, Joshi RK. Antipsoriatic effects of fumaric acid derivatives. Results of a multicenter double-blind study in 100 patients. J Am Acad Dermatol 1994;30, 977-981.

30. Baati T, Horcajada P, Gref R, Couvreur P, Serre C. Quantification of fumaric acid in liver, spleen and urine by high-performance liquid chromatography coupled to photodiode-array detection. J Pharm Biomed Anal 2011;56:758-762. 
31. Cherrington CA, Hinton M, Mead GC, Chopra I. Organic acid Chemistry, Antibacterial activity and practical applications. Adv Microb Physiol 1991;32:87107.

32. Russell JB. Another explanation for the toxicity of fermentation acids at low $\mathrm{pH}$ : anion accumulation versus uncoupling. J Appl Bacteriol 1992;73:363-370.

33. Carocho M, Ferreira ICFR. A review on antioxidants, prooxidants and related controversy: Natural and synthetic compounds, screening and analysis methodologies and future perspectives. Food Chem Toxicol 2013;51:15-25.

34. Reis FS, Ferreira ICFR, Barros L, Martins A.A comparative study of tocopherols composition and antioxidant properties of in vivo and in vitro ectomycorrhizal fungi. LWT 2011;44:820-824.

35. Reis FS, Ferreira ICFR, Barros L, Santos-Buelga C, Martins A. Mycorrhizal induction of phenolic compounds and antioxidant properties of fungi and seedlings during the early steps of symbiosis. Chemoecology 2011;21:151-159.

36. Reis FS, Ferreira ICFR, Martins A.Effect of the mycorrhizal symbiosis time in the antioxidant activity of fungi and Pinus pinaster roots, stems and leaves. Ind Crop Prod 201235:211-216.

37. Salawu OS, Ogundare OA, Ola-Salawu BB, Akindahunsi AA. Antimicrobial activities of phenolic containing extracts of some tropical vegetables. Afr J Pharm Pharmacol 2011;5:486-492.

38. Stojković DS, Zivković J, Soković M, Glamočlija J, Ferreira ICFR, Janković T, Maksimović Z. Antibacterial activity of Veronica montana L. extract and of protocatechuic acid incorporated in a food system. Food Chem Toxicol 2013; $55: 209-213$ 
39. Barnabas CGG, Nagarajan S. Antimicrobial activity of flavonoids of some medicinal plants. Fitoterapia 1988;59:508-510.

40. Denyer SP. Mechanisms of action of biocides. Int Biodeterior Biodegrad 1999;26:89-100.

41. Burton GW and Traber MG. Vitamin E: antioxidant activity, biokinetics, and bioavailability. Ann Rev Nut 1990; 10:357-382.

42. Wagner K-H, Kamal-Eldin A, Elmadfa I. Gamma-tocopherol - An underestimated vitamin? Ann Nutr Metab 2004;48:169-188.

43. Tully TP, Bergum JS, Schwarz SR, Durand SC, Howell JM, Patel RN, Cino PMJ. Improvement of sordar in production through process optimization: combining traditional approaches with DOE. Ind Microbiol Biotechnol 2007;34:193-202. 
Table 1. Composition in sugars of the studied mycelia and culture media $(\mathrm{mg} / \mathrm{g} \mathrm{dw}$; mean $\pm \mathrm{SD})$.

\begin{tabular}{|c|c|c|c|c|c|c|c|c|c|c|c|c|}
\hline & Species & Samples & Rhamnose & Xylose & Arabinose & Fructose & Glucose & Mannitol & Sucrose & Maltose & Trehalose & Total Sugars \\
\hline \multirow{6}{*}{$\begin{array}{l}\mathrm{CZ} \\
\text { Medium }\end{array}$} & \multirow{2}{*}{ P. ochrochloron } & Mycelium & $2.53 \pm 0.17^{\mathrm{dc}}$ & $3.67 \pm 0.23^{\mathrm{e}}$ & $1.29 \pm 0.09^{\mathrm{a}}$ & $10.18 \pm 0.35^{\mathrm{c}}$ & nd & $25.10 \pm 0.96^{b}$ & nd & nd & $2.26 \pm 0.01^{\mathrm{b}}$ & $45.03 \pm 1.62^{\mathrm{c}}$ \\
\hline & & Culture medium & $1.87 \pm 0.02^{\mathrm{dc}}$ & $10.35 \pm 0.04^{\mathrm{a}}$ & nd & $547.82 \pm 1.58^{\mathrm{b}}$ & $208.07 \pm 0.35^{\mathrm{c}}$ & nd & nd & nd & $5.82 \pm 0.05^{\mathrm{b}}$ & $773.93 \pm 1.86^{\mathrm{b}}$ \\
\hline & \multirow{2}{*}{ P. funiculosum } & Mycelium & $13.55 \pm 0.42^{\mathrm{a}}$ & $9.59 \pm 0.34^{\mathrm{b}}$ & nd & $533.88 \pm 33.90^{\mathrm{b}}$ & $248.77 \pm 14.14^{\mathrm{b}}$ & nd & nd & nd & $5.25 \pm 0.20^{\mathrm{cb}}$ & $811.04 \pm 49.00^{\mathrm{b}}$ \\
\hline & & Culture medium & $1.68 \pm 0.18^{\mathrm{d}}$ & $7.50 \pm 0.09^{\mathrm{c}}$ & nd & $635.63 \pm 7.94^{\mathrm{a}}$ & $400.52 \pm 14.89^{\mathrm{a}}$ & nd & nd & nd & $2.89 \pm 0.31^{\mathrm{b}}$ & $1048.19 \pm 23.04^{a}$ \\
\hline & \multirow{2}{*}{ P. verrucosum var. cyclopium } & Mycelium & $3.98 \pm 0.61^{\mathrm{b}}$ & $5.38 \pm 0.53^{\mathrm{d}}$ & $1.05 \pm 0.10^{\mathrm{b}}$ & $2.42 \pm 0.38^{\mathrm{c}}$ & nd & $76.49 \pm 4.57^{\mathrm{a}}$ & nd & nd & $9.69 \pm 1.21^{\mathrm{a}}$ & $99.01 \pm 5.38^{\mathrm{c}}$ \\
\hline & & Culture medium & $2.67 \pm 0.06^{\mathrm{c}}$ & $5.50 \pm 0.11^{\mathrm{d}}$ & nd & $23.62 \pm 0.22^{\mathrm{c}}$ & $36.20 \pm 0.31^{\mathrm{d}}$ & nd & nd & nd & $4.30 \pm 0.02^{\mathrm{c}}$ & $72.29 \pm 0.34^{\mathrm{c}}$ \\
\hline \multirow{6}{*}{$\begin{array}{l}\text { Malt } \\
\text { Medium }\end{array}$} & \multirow{2}{*}{ P. ochrochloron } & Mycelium & $1.91 \pm 0.15^{\mathrm{e}}$ & $9.46 \pm 0.49^{\mathrm{c}}$ & $4.10 \pm 0.28^{\mathrm{c}}$ & $2.63 \pm 0.16^{\mathrm{c}}$ & $58.20 \pm 1.81^{\mathrm{bc}}$ & nd & nd & nd & $5.59 \pm 0.36^{\mathrm{e}}$ & $81.89 \pm 2.53^{\mathrm{f}}$ \\
\hline & & Culture medium & $13.64 \pm 0.91^{\mathrm{b}}$ & $2.72 \pm 0.13^{\mathrm{f}}$ & nd & $8.23 \pm 1.04^{\mathrm{b}}$ & $43.49 \pm 0.63^{\mathrm{d}}$ & $67.33 \pm 0.56^{\mathrm{b}}$ & $10.48 \pm 1.21^{\mathrm{b}}$ & $131.14 \pm 7.11^{\mathrm{a}}$ & $43.97 \pm 0.82^{\mathrm{b}}$ & $321.00 \pm 6.64^{\mathrm{b}}$ \\
\hline & \multirow{2}{*}{ P. funiculosum } & Mycelium & $4.43 \pm 0.01^{\mathrm{d}}$ & $16.39 \pm 0.35^{\mathrm{a}}$ & $7.38 \pm 0.89^{b}$ & $2.99 \pm 0.49^{b}$ & $52.00 \pm 1.51^{\mathrm{c}}$ & nd & nd & nd & $13.11 \pm 0.39^{\mathrm{d}}$ & $96.30 \pm 0.88^{\mathrm{e}}$ \\
\hline & & Culture medium & $6.51 \pm 0.48^{\mathrm{c}}$ & $7.03 \pm 0.35^{\mathrm{d}}$ & nd & $7.38 \pm 0.16^{\mathrm{b}}$ & $23.53 \pm 2.40^{\mathrm{e}}$ & $29.59 \pm 3.74^{c}$ & $21.83 \pm 5.76^{\mathrm{a}}$ & $126.20 \pm 4.17^{\mathrm{a}}$ & $37.57 \pm 0.14^{\mathrm{c}}$ & $259.64 \pm 7.20^{\mathrm{c}}$ \\
\hline & \multirow{2}{*}{ P. verrucosum var. cyclopium } & Mycelium & $4.32 \pm 0.07^{\mathrm{d}}$ & $5.17 \pm 0.12^{\mathrm{e}}$ & $13.69 \pm 0.22^{\mathrm{a}}$ & $0.89 \pm 0.09^{\mathrm{d}}$ & $67.47 \pm 1.16^{\mathrm{a}}$ & nd & nd & nd & $47.59 \pm 0.24^{\mathrm{a}}$ & $139.13 \pm 1.27^{\mathrm{d}}$ \\
\hline & & Culture medium & $78.88 \pm 0.99^{\mathrm{a}}$ & $14.57 \pm 0.51^{\mathrm{b}}$ & nd & $16.10 \pm 0.20^{\mathrm{a}}$ & $60.39 \pm 5.44^{\mathrm{ba}}$ & $86.93 \pm 2.92^{\mathrm{a}}$ & $20.42 \pm 1.53^{\mathrm{a}}$ & $75.77 \pm 0.99^{\mathrm{b}}$ & $43.34 \pm 2.19^{\mathrm{b}}$ & $396.40 \pm 6.55^{\mathrm{a}}$ \\
\hline
\end{tabular}

nd- not detected. In each column, and for each culture medium, different letters mean significant differences between species $(p<0.05)$. 
Table 2. Composition in organic acids of the studied mycelia and culture media (mg/g dw; mean $\pm \mathrm{SD})$.

\begin{tabular}{|c|c|c|c|c|c|c|c|c|c|}
\hline & Species & Samples & Oxalic Acid & Quinic Acid & Malic Acid & Citric Acid & Succinic Acid & Fumaric Acid & Total \\
\hline \multirow{6}{*}{$\begin{array}{l}\mathrm{Cz} \\
\text { Medium }\end{array}$} & \multirow{2}{*}{ P. ochrochloron } & Mycelium & $40.91 \pm 0.62^{\mathrm{c}}$ & $8.80 \pm 0.08$ & nd & $3.67 \pm 0.50^{\mathrm{a}}$ & nd & $0.16 \pm 0.01^{\mathrm{a}}$ & $53.38 \pm 0.04^{\mathrm{d}}$ \\
\hline & & Culture medium & $125.39 \pm 0.15^{\mathrm{b}}$ & nd & nd & nd & nd & $0.02 \pm 0.01^{\mathrm{b}}$ & $125.41 \pm 0.14^{\mathrm{c}}$ \\
\hline & \multirow{2}{*}{ P. funiculosum } & Mycelium & $31.94 \pm 1.22^{\mathrm{d}}$ & nd & $9.16 \pm 0.36^{\mathrm{a}}$ & $3.82 \pm 0.29^{\mathrm{a}}$ & $0.63 \pm 0.06^{\mathrm{b}}$ & $0.07 \pm 0.01^{\mathrm{b}}$ & $45.62 \pm 1.22^{\mathrm{e}}$ \\
\hline & & Culture medium & $135.60 \pm 0.15^{\mathrm{a}}$ & nd & $4.55 \pm 0.60^{\mathrm{ba}}$ & nd & $2.80 \pm 0.89^{\mathrm{a}}$ & $0.06 \pm 0.02^{\mathrm{b}}$ & $143.02 \pm 1.67^{\mathrm{a}}$ \\
\hline & \multirow{2}{*}{ P. verrucosum var. cyclopium } & Mycelium & $36.68 \pm 2.92^{\mathrm{d}}$ & nd & $1.51 \pm 0.10^{\mathrm{b}}$ & nd & nd & $0.10 \pm 0.00^{\mathrm{b}}$ & $38.30 \pm 3.02^{\mathrm{e}}$ \\
\hline & & Culture medium & $132.82 \pm 0.73^{\mathrm{a}}$ & nd & $3.85 \pm 0.81^{\mathrm{ba}}$ & nd & nd & $0.09 \pm 0.02^{\mathrm{b}}$ & $136.77 \pm 0.10^{\mathrm{b}}$ \\
\hline \multirow{6}{*}{$\begin{array}{l}\text { Malt } \\
\text { Medium }\end{array}$} & \multirow{2}{*}{ P. ochrochloron } & Mycelium & $2.34 \pm 0.03^{\mathrm{c}}$ & nd & nd & nd & nd & $\operatorname{tr}$ & $2.34 \pm 0.03^{\mathrm{d}}$ \\
\hline & & Culture medium & $13.11 \pm 0.17^{\mathrm{a}}$ & $21.67 \pm 1.50^{\mathrm{a}}$ & nd & nd & nd & $0.15 \pm 0.00^{\mathrm{b}}$ & $34.94 \pm 1.34^{\mathrm{c}}$ \\
\hline & \multirow{2}{*}{ P. funiculosum } & Mycelium & $1.26 \pm 0.01^{\mathrm{d}}$ & $0.31 \pm 0.01^{\mathrm{b}}$ & $1.27 \pm 0.19^{\mathrm{c}}$ & $10.31 \pm 0.54^{\mathrm{c}}$ & $9.26 \pm 0.84^{\mathrm{b}}$ & $0.13 \pm 0.00^{\mathrm{b}}$ & $22.55 \pm 1.20^{\mathrm{c}}$ \\
\hline & & Culture medium & $2.66 \pm 0.06^{\mathrm{b}}$ & $6.64 \pm 0.70^{\mathrm{ba}}$ & $32.03 \pm 0.90^{\mathrm{a}}$ & $77.22 \pm 4.87^{\mathrm{b}}$ & $63.38 \pm 11.34^{\mathrm{a}}$ & $0.36 \pm 0.00^{\mathrm{a}}$ & $182.29 \pm 15.95^{\mathrm{a}}$ \\
\hline & \multirow{2}{*}{ P. verrucosum var. cyclopium } & Mycelium & $0.24 \pm 0.01^{\mathrm{e}}$ & $1.08 \pm 0.20^{\mathrm{ba}}$ & $1.63 \pm 0.08^{\mathrm{c}}$ & $4.78 \pm 0.06^{\mathrm{d}}$ & $2.62 \pm 0.19^{\mathrm{c}}$ & $0.10 \pm 0.00^{\mathrm{b}}$ & $10.45 \pm 0.51^{\mathrm{dc}}$ \\
\hline & & Culture medium & $1.41 \pm 0.07^{\mathrm{d}}$ & $1.48 \pm 0.14^{\mathrm{ba}}$ & $4.18 \pm 0.17^{\mathrm{b}}$ & $108.77 \pm 1.25^{\mathrm{a}}$ & $7.53 \pm 0.14^{\mathrm{cb}}$ & $0.26 \pm 0.01^{\mathrm{a}}$ & $123.67 \pm 1.08^{b}$ \\
\hline
\end{tabular}

nd- not detected; tr- trace.In each column, and for each culture medium, different letters mean significant differences between species $(p<0.05)$. 
Table 3. Composition in phenolic acids of the studied mycelia and culture media ( $\mu \mathrm{g} / \mathrm{g}$ extract; mean $\pm \mathrm{SD})$

\begin{tabular}{|c|c|c|c|c|c|c|c|}
\hline & Species & Samples & Protocatechuic acid & $p$-Hydroxybenzoic acid & $p$-Coumaric acid & Cinnamic acid & Total \\
\hline \multirow{6}{*}{$\begin{array}{l}\mathrm{CZ} \\
\text { Medium }\end{array}$} & \multirow{2}{*}{ P. ochrochloron } & Mycelium & $53.51 \pm 9.36^{\mathrm{a}}$ & $0.10 \pm 0.12^{\mathrm{a}}$ & nd & $0.26 \pm 0.07^{\mathrm{b}}$ & $53.88 \pm 9.31 \mathrm{a}$ \\
\hline & & Culture medium & nd & $0.04 \pm 0.02^{\mathrm{b}}$ & nd & $0.02 \pm 0.00^{\mathrm{a}}$ & $0.06 \pm 0.01 b$ \\
\hline & \multirow{2}{*}{ P. funiculosum } & Mycelium & $6.93 \pm 0.44^{\mathrm{c}}$ & $0.04 \pm 0.00^{\mathrm{b}}$ & $\operatorname{tr}$ & $0.03 \pm 0.01^{\mathrm{c}}$ & $7.00 \pm 0.46 \mathrm{c}$ \\
\hline & & Culture medium & $1.45 \pm 0.29$ & $0.92 \pm 0.07^{\mathrm{a}}$ & nd & $0.01 \pm 0.00^{\mathrm{a}}$ & $2.38 \pm 0.22 \mathrm{a}$ \\
\hline & \multirow{2}{*}{ P. verrucosum var. cyclopium } & Mycelium & $8.35 \pm 0.34^{b}$ & $0.02 \pm 0.00^{\mathrm{b}}$ & $\operatorname{tr}$ & $1.54 \pm 0.13^{\mathrm{a}}$ & $9.91 \pm 0.47 b$ \\
\hline & & Culture medium & nd & nd & nd & nd & - \\
\hline \multirow{6}{*}{$\begin{array}{l}\text { Malt } \\
\text { Medium }\end{array}$} & \multirow{2}{*}{ P. ochrochloron } & Mycelium & nd & nd & nd & nd & - \\
\hline & & Culture medium & nd & nd & nd & nd & - \\
\hline & \multirow{2}{*}{ P. funiculosum } & Mycelium & $11.95 \pm 0.45^{\mathrm{a}}$ & $2.29 \pm 0.24^{\mathrm{b}}$ & nd & $1.14 \pm 0.06$ & $15.38 \pm 0.75^{\mathrm{b}}$ \\
\hline & & Culture medium & nd & nd & nd & $7.03 \pm 0.39$ & $7.03 \pm 0.39$ \\
\hline & \multirow{2}{*}{ P. verrucosum var. cyclopium } & Mycelium & $8.09 \pm 2.86^{\mathrm{b}}$ & $68.84 \pm 1.15^{\mathrm{a}}$ & $8.52 \pm 0.02$ & nd & $85.46 \pm 1.69^{\mathrm{a}}$ \\
\hline & & Culture medium & nd & nd & nd & nd & - \\
\hline
\end{tabular}

nd- not detected; tr- trace. In each column, and for each culture medium, different letters mean significant differences between species $(p<0.05)$. 
Table 4. Composition in tocopherols of the studied mycelia and culture media ( $\mu \mathrm{g} / \mathrm{g} \mathrm{dw}$; mean $\pm \mathrm{SD})$.

\begin{tabular}{|c|c|c|c|c|c|c|c|}
\hline & Species & Samples & $\alpha$-Tocopherol & $\beta$-Tocopherol & $\gamma$-Tocopherol & $\delta$-Tocopherol & Total Tocopherols \\
\hline \multirow{6}{*}{ Cz Medium } & \multirow{2}{*}{ P. ochrochloron } & Mycelium & $0.64 \pm 0.03^{\mathrm{a}}$ & $0.65 \pm 0.03^{\mathrm{a}}$ & $8.93 \pm 0.37^{b}$ & $1.34 \pm 0.01^{\mathrm{a}}$ & $11.53 \pm 0.44^{\mathbf{b}}$ \\
\hline & & Culture medium & nd & nd & nd & nd & nd \\
\hline & \multirow{2}{*}{ P. funiculosum } & Mycelium & $0.38 \pm 0.01^{\mathrm{b}}$ & $0.18 \pm 0.03^{\mathrm{b}}$ & $0.20 \pm 0.00^{\mathrm{c}}$ & nd & $0.76 \pm 0.04^{\mathbf{c}}$ \\
\hline & & Culture medium & nd & nd & nd & nd & nd \\
\hline & \multirow{2}{*}{ P. verrucosum var. cyclopium } & Mycelium & $0.03 \pm 0.00^{\mathrm{c}}$ & nd & $40.69 \pm 0.14^{\mathrm{a}}$ & $0.23 \pm 0.00^{\mathrm{b}}$ & $40.96 \pm 0.14^{\mathrm{a}}$ \\
\hline & & Culture medium & nd & nd & nd & nd & nd \\
\hline \multirow{6}{*}{ Malt Medium } & \multirow{2}{*}{ P. ochrochloron } & Mycelium & $0.01 \pm 0.00^{\mathrm{d}}$ & nd & $0.83 \pm 0.01^{\mathrm{a}}$ & nd & $0.84 \pm 0.02^{\mathrm{a}}$ \\
\hline & & Culture medium & nd & nd & nd & nd & nd \\
\hline & \multirow{2}{*}{ P. funiculosum } & Mycelium & $0.04 \pm 0.00^{\mathrm{c}}$ & $0.10 \pm 0.00^{\mathrm{a}}$ & $0.04 \pm 0.01^{\mathrm{d}}$ & nd & $0.19 \pm 0.01^{\mathrm{d}}$ \\
\hline & & Culture medium & nd & nd & nd & nd & nd \\
\hline & \multirow{2}{*}{ P. verrucosum var. cyclopium } & Mycelium & $0.18 \pm 0.03^{\mathrm{b}}$ & nd & $0.32 \pm 0.01^{\mathrm{b}}$ & nd & $0.50 \pm 0.02^{\mathrm{c}}$ \\
\hline & & Culture medium & $0.36 \pm 0.01^{\mathrm{a}}$ & nd & $0.24 \pm 0.04^{\mathrm{c}}$ & $0.09 \pm 0.01^{\mathrm{a}}$ & $0.69 \pm 0.03^{b}$ \\
\hline
\end{tabular}

nd- not detected. In each column, and for each culture medium, different letters mean significant differences between species $(p<0.05)$. 
Table 5. Antioxidant properties of the phenolic extracts of the studied mycelia and culture media (mean $\pm \mathrm{SD})$.

\begin{tabular}{|c|c|c|c|c|c|c|}
\hline & Species & Samples & $\begin{array}{l}\text { Folin-Ciocalteuassay } \\
\text { (mg GAE/g extract) }\end{array}$ & $\begin{array}{l}\text { Ferricyanide/Prussian blue } \\
\text { assay }\left(\mathrm{EC}_{50} ; \mathrm{mg} / \mathrm{mL}\right)\end{array}$ & $\begin{array}{l}\text { DPPH scavenging activity } \\
\text { assay }\left(\mathrm{EC}_{50} ; \mathrm{mg} / \mathrm{mL}\right)\end{array}$ & $\begin{array}{l}\beta \text {-carotene } / \text { linoleate } \\
\text { assay }\left(\mathrm{EC}_{50} ; \mathrm{mg} / \mathrm{mL}\right)\end{array}$ \\
\hline \multirow{6}{*}{ Cz Medium } & \multirow{2}{*}{ P. ochrochloron } & Mycelium & $17.59 \pm 0.07^{\mathrm{b}}$ & $4.32 \pm 0.66^{\mathrm{d}}$ & $6.50 \pm 0.33^{\mathrm{d}}$ & $0.87 \pm 0.25^{\mathrm{d}}$ \\
\hline & & Culture medium & $7.49 \pm 0.12^{\mathrm{c}}$ & $3.80 \pm 0.13^{\mathrm{d}}$ & $58.33 \pm 2.28^{\mathrm{b}}$ & $30.78 \pm 4.85^{\mathrm{b}}$ \\
\hline & \multirow{2}{*}{ P. funiculosum } & Mycelium & $6.84 \pm 0.09^{\mathrm{d}}$ & $16.80 \pm 0.77^{\mathrm{a}}$ & $19.73 \pm 0.54^{\mathrm{c}}$ & $2.38 \pm 0.86^{\mathrm{d}}$ \\
\hline & & Culture medium & $1.75 \pm 0.17^{\mathrm{e}}$ & $10.12 \pm 0.95^{\mathrm{a}}$ & $139.85 \pm 3.49^{\mathrm{a}}$ & $10.09 \pm 2.39^{\mathrm{c}}$ \\
\hline & \multirow{2}{*}{ P. verrucosum var. cyclopium } & Mycelium & $28.73 \pm 0.40^{\mathrm{a}}$ & $2.81 \pm 0.32^{\mathrm{e}}$ & $2.31 \pm 0.08^{\mathrm{d}}$ & $0.11 \pm 0.05^{\mathrm{d}}$ \\
\hline & & Culture medium & $2.69 \pm 0.24^{\mathrm{f}}$ & $6.59 \pm 0.39^{\mathrm{c}}$ & $140.04 \pm 17.66^{\mathrm{a}}$ & $60.71 \pm 1.08^{\mathrm{a}}$ \\
\hline \multirow{6}{*}{ Malt Medium } & \multirow{2}{*}{ P. ochrochloron } & Mycelium & $31.71 \pm 0.77^{\mathrm{b}}$ & $3.36 \pm 0.04^{\mathrm{d}}$ & $9.05 \pm 0.17^{\mathrm{c}}$ & $0.39 \pm 0.07^{\mathrm{de}}$ \\
\hline & & Culture medium & $8.76 \pm 0.11^{\mathrm{f}}$ & $5.76 \pm 0.02^{\mathrm{a}}$ & $26.12 \pm 1.45^{\mathrm{a}}$ & $14.34 \pm 0.41^{\mathrm{a}}$ \\
\hline & \multirow{2}{*}{ P. funiculosum } & Mycelium & $21.12 \pm 0.16^{\mathrm{d}}$ & $5.69 \pm 0.04^{\mathrm{b}}$ & $7.00 \pm 0.17^{\mathrm{d}}$ & $0.17 \pm 0.11^{\mathrm{e}}$ \\
\hline & & Culture medium & $13.45 \pm 0.10^{\mathrm{e}}$ & $3.72 \pm 0.08^{\mathrm{c}}$ & $18.86 \pm 0.55^{\mathrm{b}}$ & $1.03 \pm 0.11^{\mathrm{c}}$ \\
\hline & \multirow{2}{*}{ P. verrucosum var. cyclopium } & Mycelium & $55.83 \pm 2.11^{\mathrm{a}}$ & $1.29 \pm 0.00^{\mathrm{f}}$ & $5.45 \pm 0.06^{\mathrm{e}}$ & $0.85 \pm 0.01^{\mathrm{dc}}$ \\
\hline & & Culture medium & $23.80 \pm 0.23^{\mathrm{c}}$ & $2.76 \pm 0.01^{\mathrm{e}}$ & $26.52 \pm 2.21^{\mathrm{a}}$ & $1.68 \pm 0.96^{\mathrm{b}}$ \\
\hline
\end{tabular}

In each column, and for each culture medium, different letters mean significant differences between species $(p<0.05)$. Concerning the Folin-Ciocalteu assay, higher values mean higher reducing power; for the other assays, the results are presented in $\mathrm{EC}_{50}$ values, what means that higher values correspond to lower reducing power or antioxidant potential.EC F0 $_{0}$ : Extract concentration corresponding to $50 \%$ of antioxidant activity or 0.5 of absorbance for the Ferricyanide/Prussian blue assay. 
Table 6.Antimicrobial activity of the organic acids extracts and individual compounds of the studied mycelia and culture media by TLC bioautography method (expressed as diameters of inhibition zones $(\mathrm{mm})$, mean $\pm \mathrm{SD})$

\begin{tabular}{|c|c|c|c|c|c|c|c|c|}
\hline & \multirow{3}{*}{ Species } & \multirow{3}{*}{ Samples } & \multicolumn{3}{|c|}{ S. aureus } & \multicolumn{3}{|c|}{ C.albicans } \\
\hline & & & 5 & 10 & 20 & 5 & 10 & 20 \\
\hline & & & $\mathrm{mg} / \mathrm{spot}$ & $\mathrm{mg} / \mathrm{spot}$ & $\mathrm{mg} / \mathrm{spot}$ & $\mathrm{mg} / \mathrm{spot}$ & $\mathrm{mg} / \mathrm{spot}$ & $\mathrm{mg} / \mathrm{spot}$ \\
\hline \multirow{6}{*}{$\mathrm{Cz}$ Medium } & \multirow{2}{*}{ P. ochrochloron } & Mycelium & $7.0 \pm 1.00^{\mathrm{a}}$ & $10.67 \pm 0.58^{\mathrm{a}}$ & $14.67 . \pm 1.53^{\mathrm{a}}$ & - & $7.0 \pm 1.00$ & $8.67 \pm 0.58^{\mathrm{a}}$ \\
\hline & & Culture medium & $9.67 \pm 0.58^{\mathrm{ab}}$ & $13.0 \pm 1.00^{\mathrm{a}}$ & $16.0 \pm 2.00^{\mathrm{a}}$ & - & - & $10.67 \pm 0.58^{\mathrm{a}}$ \\
\hline & \multirow{2}{*}{ P. funiculosum } & Mycelium & $8.67 \pm 0.58^{\mathrm{a}}$ & $10.67 \pm 1.15^{\mathrm{a}}$ & $15.33 \pm 2.31^{\mathrm{a}}$ & - & - & $8.67 \pm 1.15^{\mathrm{a}}$ \\
\hline & & Culture medium & $10.67 \pm 1.15^{\mathrm{a}}$ & $12.33 \pm 058^{\mathrm{a}}$ & $16.67 \pm 0.58^{\mathrm{a}}$ & - & $6.67 \pm 1.15^{\mathrm{a}}$ & $9.67 \pm 1.15^{\mathrm{a}}$ \\
\hline & \multirow{2}{*}{ P. verrucosum var. cyclopium } & Mycelium & $8.00 \pm 1.00^{\mathrm{a}}$ & $11.33 \pm 0.58^{\mathrm{a}}$ & $14.0 \pm 1.00^{\mathrm{a}}$ & - & - & $10.0 \pm 0.00^{\mathrm{a}}$ \\
\hline & & Culture medium & $8.67 \pm 0.58^{\mathrm{b}}$ & $12.0 \pm 2.00^{\mathrm{a}}$ & $17.67 \pm 0.58^{\mathrm{a}}$ & - & $7.67 \pm 0.58^{\mathrm{a}}$ & $11.0 \pm 1.00^{\mathrm{a}}$ \\
\hline \multirow{6}{*}{ Malt Medium } & \multirow{2}{*}{ P. ochrochloron } & Mycelium & $6.67 \pm 1.15^{\mathrm{ab}}$ & $10.67 \pm 1.15^{\mathrm{ab}}$ & $15.67 \pm 1.53^{\mathrm{ab}}$ & - & - & $7.33 \pm 0.58^{\mathrm{a}}$ \\
\hline & & Culture medium & $7.00 \pm 0.00^{\mathrm{a}}$ & $13.33 \pm 1.53^{\mathrm{a}}$ & $16.0 \pm 1.00^{\mathrm{a}}$ & - & - & $7.67 \pm 1.15^{\mathrm{a}}$ \\
\hline & \multirow{2}{*}{ P. funiculosum } & Mycelium & $9.67 \pm 1.15^{\mathrm{a}}$ & $13.0 \pm 1.00 \mathrm{a}$ & $16.33 \pm 1.53^{\mathrm{a}}$ & - & $5.33 \pm 0.58^{\mathrm{a}}$ & $9.67 \pm 1.15^{\mathrm{a}}$ \\
\hline & & Culture medium & $9.67 \pm 1.15^{\mathrm{a}}$ & $12.67 \pm 1.53^{\mathrm{a}}$ & $15.33 \pm 2.09^{\mathrm{a}}$ & - & - & $10.00 \pm 1.00^{\mathrm{a}}$ \\
\hline & \multirow{2}{*}{ P. verrucosum var. cyclopium } & Mycelium & $5.67 \pm 1.15^{\mathrm{b}}$ & $8.0 \pm 1.00^{\mathrm{b}}$ & $11.0 \pm 2.65^{\mathrm{b}}$ & - & $6.67 \pm 1.53$ & $8.33 \pm 1.15^{\mathrm{a}}$ \\
\hline & & Culture medium & $10.33 \pm 1.53^{\mathrm{a}}$ & $13.0 \pm 1.00^{\mathrm{a}}$ & $18.33 \pm 1.53^{\mathrm{a}}$ & $4.00 \pm 0.00$ & $8.0 \pm 1.00^{\mathrm{a}}$ & $10.33 \pm 0.58^{\mathrm{a}}$ \\
\hline \multirow{6}{*}{ Compounds } & Oxalic Acid & & $7.00 \pm 0.00^{\mathrm{b}}$ & $10.67 \pm 0.58^{\mathrm{a}}$ & $16.0 \pm 1.00^{\mathrm{a}}$ & - & $8.33 \pm 1.15^{b}$ & $10.67 \pm 0.58^{\mathrm{b}}$ \\
\hline & QuinicAcid & & $5.33 \pm 0.58^{\mathrm{d}}$ & $6.67 \pm 1.15^{\mathrm{bc}}$ & $10.33 \pm 1.15^{\mathrm{c}}$ & - & - & - \\
\hline & MalicAcid & & $8.00 \pm 0.00^{\mathrm{a}}$ & $11.0 \pm 1.00^{\mathrm{a}}$ & $15.33 \pm 1.15^{\mathrm{ab}}$ & - & - & - \\
\hline & CitricAcid & & $6.00 \pm 0.00^{\mathrm{c}}$ & $8.67 \pm 0.58^{\mathrm{ab}}$ & $15.67 \pm 0.58^{\mathrm{ab}}$ & - & - & - \\
\hline & Succinic Acid & & - & - & $7.00 \pm 0.00^{\mathrm{d}}$ & - & - & - \\
\hline & Fumaric Acid & & - & $9.67 . \pm 1.53^{\mathrm{a}}$ & $13.67 . \pm 0.58^{\mathrm{b}}$ & - & $8.0 \pm 1.00^{\mathrm{b}}$ & $11.67 \pm 2.08^{\mathrm{b}}$ \\
\hline \multirow{2}{*}{$\begin{array}{l}\text { Positive } \\
\text { controls }\end{array}$} & Streptomycin & & - & $5.00 \pm 0.00^{\mathrm{c}}$ & $5.00 \pm 0.00^{\mathrm{d}}$ & $\mathrm{nt}$ & $\mathrm{nt}$ & $\mathrm{nt}$ \\
\hline & Fluconazole & & $\mathrm{nt}$ & nt & $\mathrm{nt}$ & $11.67 \pm 2.10$ & $14.00 \pm 1.00^{\mathrm{a}}$ & $15.00 \pm 1.00^{\mathrm{a}}$ \\
\hline
\end{tabular}

nt- not tested. In each column, and for each culture medium or compounds, different letters mean significant differences between species $(p<0.05)$. 
Table 7. Antimicrobial activity of the phenolic acids extractsand individual compounds of the studied mycelia and culture media by TLC bioautography method (expressed as diameters of inhibition zones $(\mathrm{mm})$, mean $\pm \mathrm{SD}$ ).

\begin{tabular}{|c|c|c|c|c|c|c|c|c|}
\hline & \multirow[b]{3}{*}{ Species } & \multirow[b]{3}{*}{ Samples } & \multicolumn{3}{|c|}{ S. aureus } & \multicolumn{3}{|c|}{ C.albicans } \\
\hline & & & 5 & 10 & 20 & 5 & 10 & 20 \\
\hline & & & $\mathrm{mg} / \mathrm{spot}$ & $\mathrm{mg} / \mathrm{spot}$ & $\mathrm{mg} / \mathrm{spot}$ & $\mathrm{mg} / \mathrm{spot}$ & $\mathrm{mg} / \mathrm{spot}$ & $\mathrm{mg} / \mathrm{spot}$ \\
\hline \multirow{5}{*}{ Cz Medium } & \multirow{2}{*}{ P. ochrochloron } & Mycelium & $9.67 \pm 1.54$ & $12.33 \pm 0.58^{\mathrm{a}}$ & $18.00 \pm 2.00^{\mathrm{a}}$ & $6.00 \pm 1.00$ & $8.67 \pm 1.53$ & $11.33 \pm 0.58$ \\
\hline & & Culture medium & - & $8.67 \pm 0.58$ & $11.00 \pm 1.00^{\mathrm{a}}$ & - & - & - \\
\hline & P. funiculosum & Mycelium & - & $8.00 \pm 1.00^{\mathrm{b}}$ & $10.67 \pm 1.54^{\mathrm{b}}$ & - & - & - \\
\hline & \multirow{2}{*}{ P. verrucosum var. cyclopium } & Mycelium & - & $8.33 \pm 1.15^{\mathrm{b}}$ & $10.33 \pm 1.15^{\mathrm{b}}$ & & & \\
\hline & & Culture medium & - & - & $8.67 \pm 0.58^{\mathrm{b}}$ & - & - & - \\
\hline \multirow{5}{*}{ MaltMedium } & \multirow{2}{*}{ P. ochrochloron } & Mycelium & - & - & $8.0 \pm 1.00^{\mathrm{c}}$ & - & - & - \\
\hline & & Culture medium & - & $8.67 \pm 0.58^{\mathrm{a}}$ & $10.67 \pm 0.58^{\mathrm{a}}$ & - & - & - \\
\hline & \multirow{2}{*}{ P. funiculosum } & Mycelium & $6.67 \pm 0.58^{\mathrm{b}}$ & $8.33 \pm 1.15^{\mathrm{a}}$ & $11.33 \pm 1.15^{\mathrm{b}}$ & - & - & - \\
\hline & & Culture medium & - & $4.33 \pm 1.15^{\mathrm{b}}$ & $7.67 \pm 0.58^{\mathrm{b}}$ & - & - & - \\
\hline & P. verrucosum var. cyclopium & Culture medium & - & - & $7.33 \pm 0.58^{\mathrm{b}}$ & - & - & - \\
\hline & Protocatechuic acid & & $10.33 \pm 1.53^{\mathrm{a}}$ & $14.33 \pm 1.15^{\mathrm{a}}$ & $17.33 \pm 1.15^{\mathrm{a}}$ & - & - & - \\
\hline \multirow{3}{*}{ Compounds } & p-Hydroxybenzoic acid & & $12.33 \pm 1.15^{\mathrm{a}}$ & $15.67 \pm 2.31^{\mathrm{a}}$ & $17.00 \pm 4.00^{\mathrm{a}}$ & - & - & - \\
\hline & $p$-Coumaric acid & & $10.00 \pm 1.00^{\mathrm{a}}$ & $13.67 \pm 1.15^{\mathrm{a}}$ & $16.67 \pm 0.58^{\mathrm{a}}$ & $10.67 \pm 0.58^{\mathrm{b}}$ & $13.33 \pm 0.58^{\mathrm{b}}$ & $15.67 \pm 0.58^{b}$ \\
\hline & Cinnamic acid & & $4.00 \pm 1.00^{\mathrm{b}}$ & $12.00 \pm 2.00^{\mathrm{a}}$ & $16.33 \pm 2.31^{\mathrm{a}}$ & $12.00 \pm 1.00^{\mathrm{a}}$ & $15.33 \pm 0.58^{\mathrm{a}}$ & $19.00 \pm 2.65^{\mathrm{a}}$ \\
\hline \multirow{2}{*}{ Positive controls } & Streptomycin & & - & $5.00 \pm 0.00^{\mathrm{b}}$ & $5.00 \pm 0.00^{\mathrm{b}}$ & $\mathrm{nt}$ & nt & $\mathrm{nt}$ \\
\hline & Fluconazole & & $\mathrm{nt}$ & $\mathrm{nt}$ & $\mathrm{nt}$ & $11.67 \pm 2.10^{\mathrm{ab}}$ & $14.00 \pm 1.00^{\mathrm{ab}}$ & $15.00 \pm 1.00^{\mathrm{b}}$ \\
\hline
\end{tabular}


nt- not tested. In each column, and for each culture medium, different letters mean significant differences between species $(p<0.05)$. 
Table 8. Antimicrobial activity of the tocopherols extracts and individual compounds of the studied mycelia and culture media by TLC bioautography method (expressed as diameters of inhibition zones (mm), mean $\pm \mathrm{SD}$ ).

\begin{tabular}{|c|c|c|c|c|c|c|c|c|}
\hline & \multirow{3}{*}{ Species } & \multirow{3}{*}{ Samples } & \multicolumn{3}{|c|}{ S. aureus } & \multicolumn{3}{|c|}{ C.albicans } \\
\hline & & & 5 & 10 & 20 & 5 & 10 & 20 \\
\hline & & & $\mathrm{mg} / \mathrm{spot}$ & $\mathrm{mg} / \mathrm{spot}$ & $\mathrm{mg} / \mathrm{spot}$ & $\mathrm{mg} / \mathrm{spot}$ & $\mathrm{mg} / \mathrm{spot}$ & $\mathrm{mg} / \mathrm{spot}$ \\
\hline \multirow{6}{*}{ Cz Medium } & \multirow{2}{*}{ P. ochrochloron } & Mycelium & $8.33 \pm 0.58^{b}$ & $11.0 \pm 1.67^{b}$ & $14.67 \pm 0.58^{b}$ & $6.33 \pm 1.15^{\mathrm{a}}$ & $6.67 \pm 0.58^{b}$ & $8.67 \pm 1.52^{\mathrm{a}}$ \\
\hline & & Culture medium & $5.00 \pm 0.00^{\mathrm{b}}$ & $6.00 \pm 0.00^{\mathrm{b}}$ & $11.00 \pm 0.00^{\mathrm{a}}$ & - & - & - \\
\hline & \multirow{2}{*}{ P. funiculosum } & Mycelium & $9.33 \pm 1.17^{\mathrm{b}}$ & $11.33 \pm 2.10^{\mathrm{b}}$ & $15.67 \pm 1.17^{\mathrm{ab}}$ & $7.00 \pm 1.00^{\mathrm{a}}$ & $7.67 \pm 0.58^{\mathrm{a}}$ & $8.00 \pm 0.00^{\mathrm{a}}$ \\
\hline & & Culture medium & $8.67 \pm 1.20^{\mathrm{a}}$ & $10.33 \pm 0.57^{\mathrm{a}}$ & $10.67 \pm 2.30^{\mathrm{ab}}$ & - & - & $7.67 \pm 0.58$ \\
\hline & \multirow{2}{*}{ P. verrucosum var. cyclopium } & Mycelium & $13.33 \pm 0.58^{\mathrm{a}}$ & $13.67 \pm 0.58^{\mathrm{a}}$ & $16.33 \pm 0.58^{\mathrm{a}}$ & $5.67 \pm 1.15^{\mathrm{a}}$ & $5.67 \pm 1.15^{\mathrm{b}}$ & $8.00 \pm 0.00^{\mathrm{a}}$ \\
\hline & & Culture medium & $9.00 \pm 1.00^{\mathrm{a}}$ & $9.00 \pm 1.00^{\mathrm{a}}$ & $9.00 \pm 1.00^{\mathrm{b}}$ & - & - & - \\
\hline \multirow{6}{*}{ Malt Medium } & \multirow{2}{*}{ P. ochrochloron } & Mycelium & $9.33 \pm 0.58^{\mathrm{a}}$ & $11.67 \pm 0.58^{\mathrm{a}}$ & $15.67 \pm 1.50^{\mathrm{a}}$ & - & - & $8.67 \pm 0.58^{\mathrm{a}}$ \\
\hline & & Culture medium & $5.67 \pm 0.58^{\mathrm{b}}$ & $9.33 \pm 0.58^{b}$ & $17.00 \pm 1.00^{\mathrm{ab}}$ & - & - & - \\
\hline & \multirow{2}{*}{ P. funiculosum } & Mycelium & - & $12.67 \pm 1.50^{\mathrm{a}}$ & $13.33 \pm 2.90^{\mathrm{a}}$ & - & - & - \\
\hline & & Culture medium & $10.67 \pm 1.50^{\mathrm{a}}$ & $13.67 \pm 0.58^{\mathrm{a}}$ & $17.33 \pm 0.58^{\mathrm{a}}$ & - & $6.33 \pm 1.54^{\mathrm{a}}$ & $9.67 \pm 0.58^{\mathrm{a}}$ \\
\hline & \multirow{2}{*}{$P$. verrucosum var. cyclopium } & Mycelium & $8.00 \pm 0.00^{\mathrm{b}}$ & $13.00 \pm 0.00^{\mathrm{a}}$ & $16.33 \pm 2.10^{\mathrm{a}}$ & $5.00 \pm 0.00$ & $5.33 \pm 0.58$ & $8.00 \pm 1.00^{\mathrm{a}}$ \\
\hline & & Culture medium & $7.67 \pm 0.58^{\mathrm{b}}$ & $11.0 \pm 1.00^{\mathrm{b}}$ & $15.33 \pm 0.58^{\mathrm{b}}$ & $6.00 \pm 1.00$ & $7.00 \pm 0.00^{\mathrm{a}}$ & $8.00 \pm 1.00^{\mathrm{a}}$ \\
\hline & $\alpha$-Tocopherol & & - & - & - & - & $5.0 \pm 0.00^{\mathrm{d}}$ & $7.70 \pm 0.58^{b}$ \\
\hline \multirow{3}{*}{ Compounds } & $\beta$-Tocopherol & & - & - & - & $8.70 \pm 0.58^{\mathrm{b}}$ & $10.0 \pm 0.00^{\mathrm{bc}}$ & $13.30 \pm 2.10^{\mathrm{a}}$ \\
\hline & $\gamma$-Tocopherol & & - & $10.00 \pm 0.0^{\mathrm{a}}$ & $10.0 \pm 0.0^{\mathrm{a}}$ & - & $11.7 \pm 2.10^{\mathrm{ab}}$ & $14.00 \pm 1.67^{\mathrm{a}}$ \\
\hline & $\delta$-Tocopherol & & $5.00 \pm 0.00$ & $6.70 \pm 0.58^{\mathrm{b}}$ & $9.70 \pm 0.58^{\mathrm{a}}$ & $9.00 \pm 0.0^{\mathrm{b}}$ & $9.00 \pm 0.00^{\mathrm{c}}$ & $11.70 \pm 1.52^{\mathrm{ab}}$ \\
\hline Positive & Streptomycin & & - & $5.00 \pm 0.00^{\mathrm{c}}$ & $5.00 \pm 0.00^{\mathrm{b}}$ & $\mathrm{nt}$ & $\mathrm{nt}$ & $\mathrm{nt}$ \\
\hline controls & Fluconazole & & $\mathrm{nt}$ & $\mathrm{nt}$ & $\mathrm{nt}$ & $11.67 \pm 2.10^{\mathrm{a}}$ & $14.00 \pm 1.00^{\mathrm{a}}$ & $15.00 \pm 1.00^{\mathrm{a}}$ \\
\hline
\end{tabular}

nt- not tested. In each column, and for each culture medium, different letters mean significant differences between species $(p<0.05)$. 
Fig 1. Antimicrobial activity of the organic (A), phenolic acids (B) and tocopherols (C) extracts and standards of the studied mycelia and culture media (inhibition zones $-\mathrm{mm}$ ) by TLC bioautography method. 

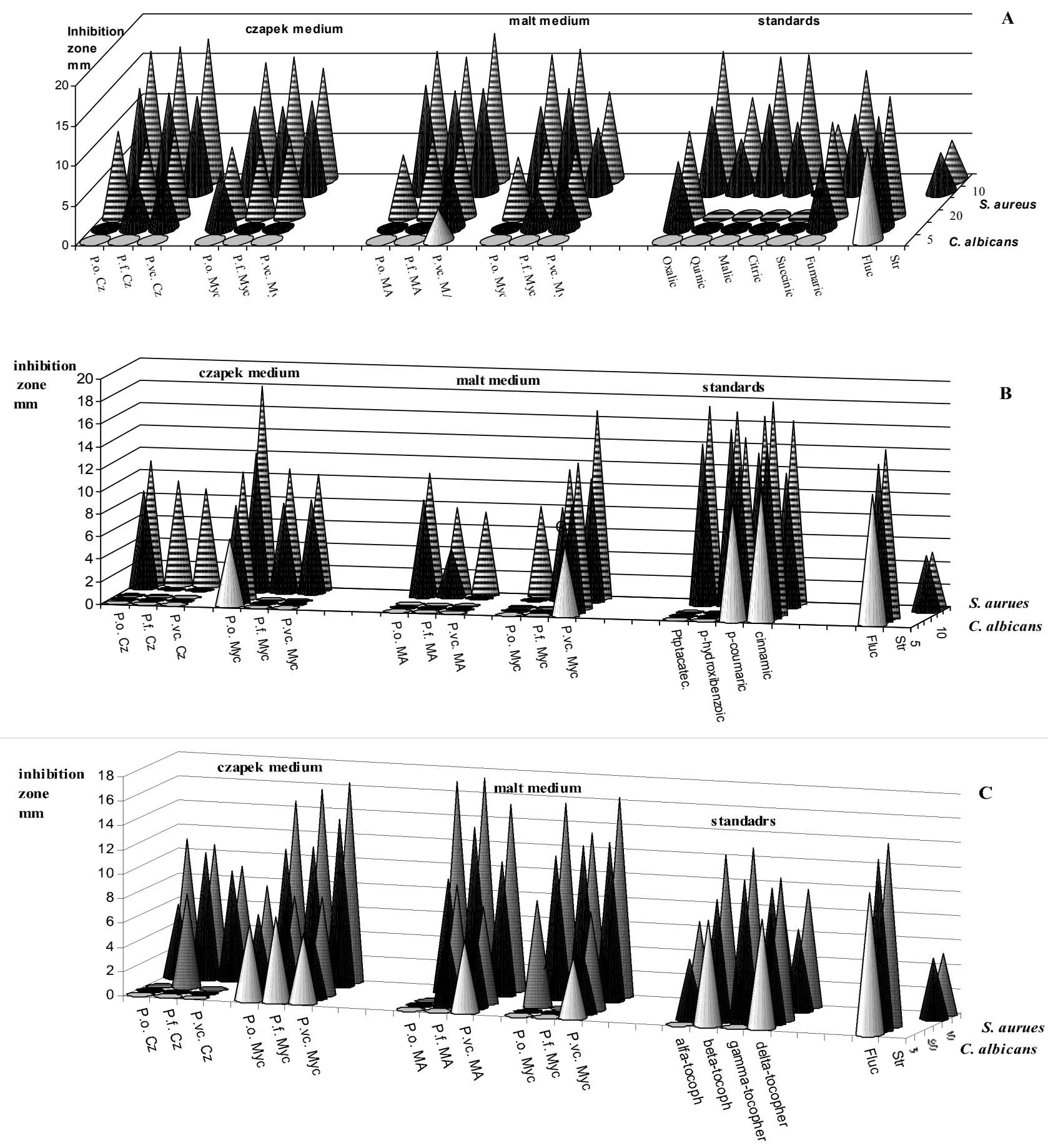

Fig 1. 